\title{
A Child with Psoriasis, Hypogammaglobulinemia, and Monosomy 7-Positive Myelodysplastic Syndrome
}

\author{
Miyelodisplastik Sendrom, Psöriazis, Hipogamaglobulinemi ve \\ Monozomi 7'si Olan Bir Çocuk Miyelodisplastik Sendrom Olgusu
}

\author{
Namık Özbek¹, Arzu Yazal Erdem¹, Özlem Arman Bilir¹, Fatma Karaca Kara², Mutlu Yüksek³, Neşe Yaralı1, \\ Meltem Özgüner ${ }^{4}$, Nazmiye Yüksek ${ }^{5}$, Bahattin Tunç1 \\ ${ }^{1}$ Ankara Children's Hematology and Oncology Hospital, Clinic of Pediatric Hematology, Ankara, Turkey \\ ${ }^{2}$ Ankara Children's Hematology and Oncology Hospital, Clinic of Biochemistry, Ankara, Turkey \\ ${ }^{3}$ Bülent Ecevit University Faculty of Medicine, Department of Children's Immunology, Ankara, Turkey \\ ${ }^{4}$ Yildırım Beyazıt University Faculty of Medicine, Department of Histology Embryology, Ankara, Turkey \\ ${ }^{5}$ Bülent Ecevit University Faculty of Medicine, Department of Pediatric Hematology, Ankara, Turkey
}

To the Editor,

A 3.5-year-old girl was admitted to our hospital with psoriasis, hypogammaglobulinemia, and pancytopenia present since 2 years of age. Before admission, due to the decreased number of B-lymphocytes and decreased immunoglobulin (Ig) levels (IgG: $196 \mathrm{mg} / \mathrm{dL}$, IgM: 18.1, IgA: $26.8 \mathrm{mg} / \mathrm{dL}$ ), she was diagnosed with autosomal recessive hypogammaglobulinemia and received intravenous Ig every month. She was referred to us after detection of $12 \%$ blasts and monosomy 7 in a bone marrow (BM) aspiration specimen. Her parents were cousins and 2 elder sisters had died of infection at 3 and 6 months of age, one of whom had had pancytopenia and hepatosplenomegaly. Physical examination revealed normal growth and diffuse psoriatic lesions. Laboratory investigations revealed hemoglobin of 8.5 $\mathrm{g} / \mathrm{dL}$, mean corpuscular volume of $92 \mathrm{fL}$, reticulocyte count of $0.4 \%$, leukocyte count of $3.7 \times 10 \% / \mathrm{L}$ (absolute neutrophil count of $0.4 \times 10^{9} / \mathrm{L}$ ), and platelet count of $28 \times 10^{9} / \mathrm{L}$ with $2 \%$ blasts on peripheral smear. Lymphocyte subset analysis revealed 1\% CD19+ cells. T-lymphocyte stimulation by phytohemagglutinin disclosed normal results. Virological, microbiological, and immunological studies; DEB test; and ferritin, vitamin B12, and folic acid levels were all unrevealing.

Bone marrow aspiration revealed 15\% blasts and BM biopsy revealed 10\%-15\% CD34+ blastic cells and trilineage dysplasia. A clonal population with monosomy 7 was detected in $70 \%$ of metaphases studied. She was diagnosed with myelodysplastic syndrome (MDS) and refractory anemia with excess of blasts (RAEB). After 3 months, a BM study before BM transplantation (BMT) showed 23\% blasts, revealing progression to acute myeloblastic leukemia (AML). After AML-BFM induction treatment, she underwent BMT from her fully matched uncle. Interestingly, her psoriatic lesions disappeared, and she is doing well 12 months after the BMT.

The only report in the literature similar to ours presented 3 children with diagnoses of hypo-/agammaglobulinemia and B-lymphocytopenia, followed by refractory anemia and monosomy 7 [1]. One of them progressed to RAEB after 6 years, similar to our patient progressing to AML. Another report described secondary transient MDS in a patient with X-linked agammaglobulinemia and a clonal abnormality in the BM $[\operatorname{del}(6 q),-9$ and $\operatorname{der}(11)]$ that disappeared within 1.5 years [2]. Secondary MDS or features mimicking MDS may be seen during viral infections, in patients with genetic abnormalities including microdeletion 22q11.2, and in nonmalignant disorders like juvenile rheumatoid arthritis, polyarteritis nodosa, and idiopathic thrombocytopenic purpura $[3,4,5,6,7]$. Informed consent was obtained.

A current hypothesis claims that in genetically predisposed persons, nonspecific stimulation of T-cells

Address for Correspondence: Arzu YAZAL ERDEM, M.D.,

Ankara Children's Hematology and Oncology Hospital, Clinic of Pediatric Hematology, Ankara, Turkey

Phone+90 3125969600 E-mail: arzu.erdem@gmail.com

Received/Geliş tarihi : July 23, 2014

Accepted/Kabul tarihi : November 7, 2014 
amplifies epidermal growth in psoriasis [8]. In the literature, the only relevant paper revealed MDS in an adult with psoriasis that occurred after etanercept treatment [9]. Although the number, distribution, and activity of T-cells were normal in our patient, the disappearance of psoriatic lesions after BMT may indicate an intrinsic T-cell defect,which is also a new finding. The promising outcome of BMT in our patient may also indicate the role of allogeneic mesenchymal stem cells in the healing of psoriasis. A recent study reported aberrant proliferative activity, increased apoptosis rate, and different gene expression profiles in bone marrow mesenchymal stem cells (BMMSCs) obtained from psoriatic patients, which lead to defective immune response [10]. The disappearance of psoriatic lesions in our patient may have been due to the immunomodulatory effect of allogeneic BMMSCs.

\section{Conflict of Interest Statement}

The authors of this paper have no conflicts of interest, including specific financial interests, relationships, and/or affiliations relevant to the subject matter or materials included.

Key Words: Psoriasis, Hypogammaglobulinemia, Monosomy 7, MDS

Anahtar Sözcükler: Psöriazis, Hipogamaglobulinemi, Monozomi 7, MDS

\section{References}

1. Srivannaboon K, Conley ME, Coustan-Smith E, Wang WC. Hypogammaglobulinemia and reduced numbers of B-cells in children with myelodysplastic syndrome. J Pediatr Hematol Oncol 2001;23:122-125.

2. Narula G, Currimbhoy Z. Transient myelodysplastic syndrome in X-linked agammaglobulinemia with a novel Btk mutation. Pediatr Blood Cancer 2008;51:826-828.
3. Yetgin S, Çetin M, Yenicesu İ, Özaltın F, Uçkan D. Acute parvovirus B19 infection mimicking juvenile myelomonocytic leukemia. Eur J Hematol 2000;65:276-278.

4. Özbek N, Derbent M, Olcay L, Yllmaz Z, Tokel K. Dysplastic changes in the peripheral blood of children with microdeletion 22q11.2. Am J Hematol 2004;77:126-131.

5. Yetgin S, Ozen S, Saatci U, Bakkaloglu A, Besbas N, Kirel B. Myelodysplastic features in juvenile rheumatoid arthritis. Am J Hematol 1997;54:166-169.

6. Yetgin S, Ozen S, Yenicesu İ, Çetin M, Bakkaloğlu A. Myelodysplastic features in polyarteritis nodosa. Pediatr Hematol Oncol 2001;2:157-160.

7. Olcay L, Yetgin S, Okur H, Erekul S, Tuncer M. Dysplastic changes in idiopathic thrombocytopenic purpura and the effect of corticosteroids to increase dysplasia and cause hyperdiploid macropolycytes. Am J Hematol 2000;65:99104.

8. Bos JD, de Rie MA, Teunissen MB, Piskin G. Psoriasis: dysregulation of innate immunity. $\mathrm{Br} \mathrm{J}$ Dermatol 2005;152:1098-1107.

9. Knudson RM, Tefferi A, Pittelkow MR, Davis MD. Development of myelodysplastic syndrome evolving to acute myeloid leukemia in a patient receiving etanercept for psoriasis. J Am Acad Dermatol 2011;65:673-674.

10. Hou R, Liu R, Niu X, Chang W, Yan X, Wang C, Li J, An P, Li X, Yin $\mathrm{G}$, Zhang K. Biological characteristics and gene expression pattern of bone marrow mesenchymal stem cells in patients with psoriasis. Exp Dermatol 2014;23:521-523. 